\title{
KEHENDAK SEJARAH: \\ INDUSTRIALISASIDAN PERUBAHAN MASYARAKAT
}

\author{
Suhatma
}

Dosen Manajemen Pendidikan Islam

FITK IAIN Syekhnurjati Cirebon

\begin{abstract}
ABSTRAK
Memasyarakatkan ide-ide baru (modernisme) dalam bentuk pembaruan ekonomi melalui industrialisasi misalnya, dibutuhkan strategi khusus agar modernisasi akan diterima masyarakat dan tidak berbenturan dengan tradisionalisme. Modernisasi tidak perlu melenyapkan aspek kehidupan tradisional, sebaliknya unsur-unsur tradisi dan kantongkantong kebudayaan tradisional dapat dipertahankan dalam masyarakat modernisasiMenurut sebagian ahli, esensi modernisasi adalah tatana social modern atau poroses menjadi modern. Sementara para ekonom, politikus, sosiolog dan ilmuwan social lainnya berbeda cara dalam memandang modernisasi, tapi mereka bertemu dalam satu kalimat yaitu bahwa esensi modernisasi sangat ditentukan oleh kepribadian setiap individu. Mereka juga sepakat mengajukan beberapa cirri modernisasi yaitu: (1) pertumbuhan ekonomi yang terus berlanjut, (2) tingkat partisipasi masyarakat dalam kepemerintahan yang memadai, 3) difusi norma skuler-rasional dalam kebudayaan, 4) peningkatan mobilitas masyarakat, 5) transformasi kepribadian individu, sehingga berfungsi secara efektif dalam tatanan social yang sesuai dengan tuntutan kemodernan. Harus diakui secara jujur bahwa secara konseptual, lembaga pra-sekolah merupakan program PLS dalam upaya penanganan terhadap permasalahan pendidikan masyarakat. Karena itu, jika PLS concern dengan upaya peningkatan kemampuan kognitif, psikomotor dan penanaman perilaku dan sikap dalam menunjang aktualisasi diri dan kemandirian peserta didik. Maka perlu dipikirkan strategi yang jitu dalam penanganan pendirtian TK, Play Group atau pra-sekolah sejenisnya.
\end{abstract}

\section{Kata Kunci: Modernisme, Industrialisasi dan Perubahan Masyarakat.}

\section{A. PENDAHULUAN}

Bagi masyarakat yang ingin maju, sangat dibutuhkan ide-ide baru dan segar dari warga bangsa dalam upaya untuk membangun sistem atau tatanan politik, ekonomi, social, budaya dan lainnya. Akan tetapi, ide baru bahkan action plan bernilai positif yang digagas seseorang atau sekelompok orang, seringkali memperoleh perlawanan sengit dari masyarakat, karena ide baru itu dinilai berbenturan dengan "ideide lama" yang telah tertanam lama dan tertata rapih di tengah-tengah masyarakat. Kenyataan ini akan lain, masyarakat akan memberikan respon positif jika ide-ide baru dan segar itu disampaikan dengan cara yang santun, elegan dan dikemas dengan bahasa masyarakat (bukan bahasa penggas).

Salah satu contoh, sebuah ide segar pada tahun 1980-an disampaikan oleh Pemda kepada masyarakat pedesaan tentang pentingnya "Membangun MCK". Tujuan dibangunnya MCK itu diinformasikan yaitu untuk menolong sebagian masyarakat yang tidak memiliki MCK dan menjaga kebersihan dari suasana yang kurang sehat. Sebagian masyarakat terhadap informasi itu beragam, sebagian ada yang menyambut baik, sebagian lagi tidak simpatik dan sebagian dari mereka ada yang berusaha menggagalkannya. Penilaian mereka yang 
berusaha menggagalkan MCK bahwa, ide itu "menjijikkan" karena MCK bukan untuk menjaga kebersihan melainkan menambah kotor lingkungan. Sehingga pembangunan MCK saat itu gagal. Setelah aparat pemerintah mendekati para tokoh masyarakat/tokoh agama, agar membantu memasyarakatkan gagasan itu, maka dua bulan kemudian di beberapa blok dibangun beberapa MCK. Kenyataan ini menginformasikan bahwa, pada awalnya ideide baru selalu membawa dampak dan menumbuhkan konflik baik antara penggagas dengan penerima gagasan ataupun antar masyarakat penerima gagasan itu sendiri. Hal ini terjadi karena "daya tangkap", cara pandang dan interes masyarakat yang amat beragam.

Contoh di atas sengaja dimunculkan untuk menggambarkan bahwa, ide baru (modernisasi) pada awalnya berbenturan dengan "ide lama" (tradisionalisme). Tapi jika ide baru itu sesuai dengan apa yang diinginkan oleh penerima ide bahkan disertai dengan cara melaksanakan ide itu, Insya Allah memasyarakatkan ide baru tidak akan banyak memperoleh hambatan. Pernyataan ini diperkuat oleh Miclin melalui Robert $\mathrm{H}$ Laurer yang menuliskan bahwa, "perubahan tradisi (ide lama) dan proses modernisme dapat terjadi secara terpisah bahkan proses modernisasi dapat memperkuat atau membantu mempertahankan aspek-aspek perubahan tradisi”.

Karena itu, untuk memasyarakatkan ide-ide baru (modernisme) dalam bentuk pembaruan ekonomi melalui industrialisasi misalnya, dibutuhkan strategi khusus agar modernisasi akan diterima masyarakat dan tidak berbenturan dengan tradisionalisme. Modernisasi tidak perlu melenyapkan aspek kehidupan tradisional, sebaliknya unsurunsur tradisi dan kantong-kantong kebudayaan tradisional dapat dipertahankan dalam masyarakat modernisasi.

Makalah ini berusaha menguraikan dan membahas tentang industrialisasi dan modernisasi serta strategi modernisasi, kemudian dikaitkan dengan urgensi PLS dalam memasyarakatkan ide-ide innoivatif kepada masyarakat.

\section{B. Modernisasi dan Industrialisasi}

Secara histories, kedua istilah ini saling berhubungan erat, saling berkepentingan bahkan dalam prosesnya kedua istilah ini saling membantu demi kepentingannya masing-masing. Padahal sesungguhnya, kedua istilah ini memiliki makna, proses, fungsi dan peranan yang berbeda. Di beberapa negara maju, salah satu penyebab modernisasi adalah tumbuhnya industrialisasi. Tapi di beberapa negara lain, modernisasi merupakan penyebab industrialisasi. Karena itu, baik modernisasi maupun industrialisasi keduanya menyangkut pertumbuhan ekonomi. Akan tetapi jika dipelajari dari prosesnya, maka modernisasi lebih inkluasif katimbang industriliasi, karena modernisasi dapat terjadi di semua sector kehidupan manusia walaupun tanpa didahului atau dibantu adanya proses industrialisasi.

Industrialisasi adalah pembangunan ekonomi melalui transformasi sumber daya dan kuantitas energi yang digunakan, sedangkan modernisasi adalah seluruh perubahan social politik yang menyertai industrialisasi. Perbedaan antara modernisasi dengan industrialisasi adalah, modernisasi dalam sector ekonomi mungkin didasarkan atau tidak didasarkan pada industrialisasi. Karena itu, modernisasi sebagai proses nonekonomi dimulai jika kebudayaan mewujudkan sikap menyelidik dan mempertanyakan tentang bagaimana manusia membuat pilihan: moral, social dan personal.

Berkaitan dengan perkembangan ekonomi, Rostow menetapkan lima tingkat pertumbuhan ekonomi yaitu: 1) tingkat tradisional. 2) syarat untuk tinggal landas, 3) tinggal landas, 4) dorongan menuju kematangan, dan 5) tingkat konsumsi masal.

Tingkat tradisional. Pada tingkat ini, catatan Rostow ditandai dengan a) keterbatasan potensi produktivitas; b) kegiatan pertanian, sangat menonjol tetapi 
produktivitasnya rendah, c) modal yang tersedia, kecil d) sementara jumlah orang yang menabungkan uanganya ke Bank jumlahnya sedikit, e) jumlah buta huruf, banyak.

Syarat untuk tinggal landas. Pada tahapan ini, ditandai dengan a) kesadaran rakyat mulai meningkat tengang kemajuan ekonomi mungkin dicapai. Keyakinan ini menimbulkan berbagai keuntungan, antara lain pertumbuhan struktur ekonomi, seperti berdirinya beberapa bank, mulai terjadi; b) kadar pendidikan berubah dalam menghadapi perubahan ekonomi. Terpentiung dari semuanya itu adalah, c) terciptanya kestabilan politik dalam bentuk pemerintah sentral semakin kuat

Tinggal landas, pada tingkat ini ditandai dengan (a) tercapainya pertumbuhan ekonomi yang cepat melalui penerapan teknik indusatri mpdern di sejumlah sector ekonomi, walaupu masih terbatas; (b) peningkatan proporesi investasi bersih terhadap pendapatan nasional di atas $10 \%$, (c) aspek non-ekonomi meliputi keberhasil sosio-politik yang melakukan modernisasi menghalami peningkatan.

Dorongan menuju kematangan, pada taap ini ditandai dengan a) penerapan teknologi modern ke seluruh sector kehidupan, b) 10-20\% pendapatan nasional diinvestasikan. Pengalaman di beberapa negara maju, untuk mencapai ke tingkat ini dibutuhkan enam tahun setelah era tinggal landas.

Tingkat konsumsi massal. Pada tingkat ini ditandai dengan a) semakin berkembangnya penggunaan teknologi modern, b) meningkatnya kesejahteraan masyarakat, c) meluasnya konsumerisme, d) berjuang untuk meningkatkan dan pengaruh di arena internasional.

Kelima tingkatan konsep Rostow tersebut di atas, berlaku bagi semua negaranegara di dunia meskipun tidak semua negara dalam proses menuju ke era tingkat konsumsi masal masing-masing tidak persis seperti konsep Rostow.

\section{a. Modernisasi dan Teori Perubahan Sosial}

Menurut sebagian ahli, esensi modernisasi adalah tatana social modern atau poroses menjadi modern. Sementara para ekonom, politikus, sosiolog dan ilmuwan social lainnya berbeda cara dalam memandang modernisasi, tapi mereka bertemu dalam satu kalimat yaitu bahwa esensi modernisasi sangat ditentukan oleh kepribadian setiap individu. Mereka juga sepakat mengajukan beberapa cirri modernisasi yaitu: (1) pertumbuhan ekonomi yang terus berlanjut, (2) tingkat partisipasi masyarakat dalam kepemerintahan yang memadai, 3) difusi norma skuler-rasional dalam kebudayaan, 4) peningkatan mobilitas masyarakat, 5) transformasi kepribadian individu, sehingga berfungsi secara efektif dalam tatanan social yang sesuai dengan tuntutan kemodernan.

Namun demikian, Dean Tipps berkomentar bahwa, berbagai perspektif tentang modernisasi sebagaimana dikemukakan di atas, hingga kini belum ada satu teori modernisasipun yang diterima secara umum. Karena itu, lanjut Tipps, konsep modernisasi masih relatif baru. Kebanyakan teori modernisasi yang disusun para ahli, dipengaruhi oleh perpektif evolusi dan fungsional structural. Konsep modernisasi digunakan hanya untuk meringkas fenomena yang sangat banyak jumlahnya daripada membedakan apa yang modern dari kondisi yang non-modern.

Berkenaan dengan belum adanya teori modernisasi yang diakui secara umum, maka Tipps dan Frank menghendaki agar teori modernisasi ditata kembali. Ini bukan berarti teori yang sudah ada tidak berguna; Ia akan berguna, terutama unsur-unsur kontradiksi, konflik antara kelompok dan sebagainya. Untuk keperluan ini, maka perlu dibahas masalah hubungan antara proses modernisasi dengan teori perubahan social.

Berkaitan dengan hal tersebut, maka Tipps mengajukan teori bahwa modernisasi dapat digolongkan ke dalam dua tipe yaitu: 1) teori variable kritis yang mencakup 
sejenis perubahan tunggal seperti industrilisasi, dan 2) teori dikotomi yang mencakup proses transformasi masyarakat tradisional menjadi masyarakat modern. Namun demikian, perlu dirumuskan terlebih dahulu persyaratan-persyaratan terbentuknya proses modernisasi.

Persyaratan apa yang diperlukan untuk terjadinya modernisasi? Berdasarkan daftar ciri-ciri kemodernan sebagaimana dikemukakan di atas, maka factor-faktor social, ekonomi dan psikologi social merupakan syarat terbentuknya modernisasi. Ketiga factor ini, dalam prakteknya dapat memperlancar sekaligus menghambat proses modernisasi. Pendapat lain mengemukakan, nilai, sikap dan perilaku adalah factor-faktor yang perlu dirubah agar terjadi modernisasi.

Berdasarkan pernyataan di atas, maka dapat dikemukakan bahwa syarat terjadinya modernisasi adalah 1) factor social, 2) factor ekonomi, 3) factor psikologi sosial, 4) factor nilai, 5) factor sikap dan 6) factor perilaku sosial.

Sementara masalah modernisasi dalam bidang ekonomi, serahkan kepada ekonom; tapi jika proses modernisasi itu dalam bidang industrialisasi, Rostow mengajukan tiga syarat yaitu: 1) pembangunan social untuk pengolahan sumber alam secara produktif dan terselenggaranya suatu pemerintahan yang efektif dan berwibawa, 2) revolusi teknologi di bidang pertanian, 3) perluasan inpor dengan meningkatkan efisiensi produksi dan pemasaran sumber alam yang berlebih.

\section{c. Akibat Modernisasi}

Menurut definisi, modernisasi menimbulkan perubahan di berbagai sector kehidupan. Setiap bentuk perubahan, selalu diiringi dengan akibat atau dampak. Akibat yang ditimbulkan oleh modernisasi, biasanya terjadi bersamaan dengan usaha modernisasi. Perubahan yang diakibatkan modernisasi, merupakan perubahan khas. Ada enam jenis perubahan akibat dari modernisasi yaitu: 1) demokrasi, 2) system stratifikasi, 3) pemerintahan, 4) pendidikan, 5) system keluarga dan 6) nilai, sikap serta kepribadian.

Perubahan sistem stratifikasi, meliputi sembilan jenis perubahan yaitu: pembagian kerja menjadi semakin rumpil, status social cenderung atas dasar prestasi, pekerjaan berfungsi sebagai alat untuk memperoleh "ganjaran" daripada sebagai "ganjaran" itu sendiri, "ganjaran" semakin meningkat, "ganjaran" didistribusikan atas dasar keadilan, peluang hidup di berbagai strata social, terjadinya pergeseran dalam distribusi "geng social" dan pergeseran dalam distribusi kekuasaan. Perubahan dalam stratifikasi social juga terjadi pada peningkatan status social wanita, di mana remaja wanita memperoleh posisi status social baru sementara wanita tua kehilangan status tingginya. Kecuali itu, status dan fungsi serta peranan organisasi mencerminkan adanya peningkatan.

Perubahan system kepemerintahan, meliputi semakin tranfarannya kecenderungan masyartakat terhadap proses demokratisasi, di mana kekuasaan politik tersebar semakin meluas ke berbagai lapisan masyarakaat. Pernyataan ini dapat diperhatikan dari jumlah persaingan politik, partisipasi masyarakat dalam berpolitik dan kesamaan perwakilan. Pada saat yang sama, karena seringnya terjadinya over-urbanisasi sehingga terciptanya sumber aktivitas yang menyimpang. Akibatnya, timbulah disorganisasi social seperti gerakan protes. Gerakan protes (demonstrasi) terbentuk, terutama karena tiga hal yaitu 1) pencarian keadilan berlandaskan pada prinsip persatuan, 2) pencarian simbol-simbol identitas perseorangan dan kolektif, 3) pencarian makna diri dalam struktur social.

Perubahan system pendidikan, meliputi perubahan kuantitatif dan kualitatif. Perubahan secara kuantitatif tampak dari pertumbuhan dan perkembangan organisasi pendidikan yang semakin meningkat. Perluasan pendidikan ini biasanya berkaitan dengan upaya Pemerintah Daerah dalam meningkatkan statusnya melalui asset lembaga pendidikan yang dimilikinya. 
Sedangkan perubahan secara kualitatif, disebabkan karena pembagian kerja yang semakin rumpil. Dengan demikian, perubahan yang terjadi pada pendidikan -baik perubahan kuantitatif maupun perubahan kualitatif-- merupakan aspek terpenting dalam pembangunan. Perubahan yang terjadi pada pendidikan amat diharapkan, agar system pendidikan mampu menyediakan individu terlatih dan memiliki motivasi yang kuat untuk membangun perekonomian.

Perubahan system keluarga, ditandai dengan urbanisasi (pergeseran status, fungsi danperanan dari kawasan pedesaan menjadi kawasan perkotaan) sehingga sering menimbulkan ketegangan hubungan antar anggota keluarga besar (masyarakat); biasanya keluarga kecil yang sering dijadikan sebagai ide utama proses modernisasi. Akibat dari urbanisasi, maka timbul dua istilah dalam keluarga yaitu keluarga tradisional dan keluarga modern. Karena itu, terjadinya perubahan dalam keluarga sangat bergantung kepada jenis perubahan dan pada jenis keluarga.

Perubahan penting yang terjadi dalam keluarga adalah, pemindahan sebagian besar fungsi dan peranan keluarga. Sering disebutsebut bahwa, dalam masyarakat tradisional pemenuhan kebutuhan ekonomi, pendidikan dan agama serta emosional kesemuanya disediakan dalam keluarga. Berbeda dalam keluarga modern, sebagian besar tanggung jawab ini diserahkan kepada unit social lai seperti pemerintah, lembaga pendidikan dan badan usaha.

Nilai, sikap serta kepribadian. Dari sekian banyak perubahan yang tejadi akibat modernisasi, perubahan yang terjadi pada tatanan nilai, sikap dan kepribadian merupakan perubahan yang sangat besar. Sebab, dampak dari perubahan ini adalah apa yang disebut sebagai "manusia modern" yaitu orang yang mampu berfungsi secara efektif dalam sebuah bangsa yang sedang mengalami pertumbuhan ekonomi, mampu berpartisipasi dalam membentuk keputusan politik.

\section{d. Terobosan Modernisasi}

Menuju

Penulis tidak setuju dengan ide pemusatan, di mana ada dikotomi antara tradisional dan modernisme. Tradisi bukanlah sesuatu yang statis; tradisi akan berubah terlepas dari proses modernisasi; bahkan menurut Miclin, tradisionalisme berubah lebih cepat dibandingkan dengan modernisme. Jika tradisionalisme dapat berubah tanpa modernisasi, maka modernismepun dapat terjadi tanpa perubahan mendasar dalam tradisi. Dengan demikian, perubahan tradisi dan poroses modernisme dapat terjadi secara terpisah dan proses modernisasi bahkan dapat memperkuat atau membantu mempertahankan aspek-aspek perubahan tradisi.

Ringkasnya, akibat modernisasi yang berbeda-beda, meskipun modernisasi mengambil bentuk khusus di Barat, namum masyarakat lain yang melaksanakan proses modernisasi tidak perlu mengikuti model Barat. Modernisasi pun tidak perlu melenyapkan aspek kehidupan tradisional. Unsur-unsur tradisi dan kantong-kantong kebudayaan tradisional dapat dipertahankan dalam masyarakat modernisasi.

\section{e. Modernisasi dan Skularisme}

Modernisasi, lambat atau cepat akan menyisihkan fungsi dan peranan agama dari kehidupan manusia. Pernyataan ini diperkuat oleh Dmitri bahwa, penerimaan terhadap ilmu pengetahuan sebagai bentuk kekalahan Tuhan. Artinya, jika ilmu pengetahuan lebih utama daripada Tuhan agama, inilah yang dimaksud skularisasi Karena ilmu pengetahuan adalah symbol rasionalitas, sedangkan Tuhan adalah symbol agama. Polarisasi antara modernisasi dan agama bagaikan polarisasi antara modernisasi dengan tradisi yaitu suatu penyimpangan dari realitas. Lalu apakah skularisasi itu?

Cox (1965:20) menuliskan skularisasi sebagai "proses histori, dimana masyarakat dan kebudayaan dibebaskan dari pengawasan dan pengendalian agama. Skularisasi 
ditentukan oleh pertimbangan social dan rasional, sementara agama hanya berfungsi sebagai salah satu sumber dari moralitasnya". Pernyataan ini dibuktikan oleh hasil survey yang dilakukan Buchanan dan Ellis (1955:78) tentang "penghambat pembangunan" terhadap pembangunan ekonomi di negara yang penganut ajaran Islamnya kuat. Kedua ekonom itu memperoleh hasil bahwa, "prestasi material dianggap sepele, hidup di dunia hanya sebagai persinggahan sementara menuju kehidupan abadi di akhirat. Menerima takdir, tawakkal, pemurah, saleh merupakan istilah yang tepat untuk melukiskan sikap mereka".

Hasil survey tersebut tampaknya bertentangan dengan teori peranan ideology dalam perubahan social. Dalam teori itu disebutkan bahwa, dalam kasus-kasus tertentu, sistem kepercayaan agama dapat mempermudah pembangunan ekonomi, sebagaimana hasil temuan Clifford Geertz di Indonesia. Memang, pada kasus kebanyakan menunjukkan bahwa, skularisasi yang menyertai modernisasi dapat menyebabkan ditinggalkannya agama. Bukti dari pernyataan terakhir ini adalah hasil penelitian McCord terhadap masyarakat Afrika dan Timur Tengah. McCord menyatakan bahwa, "orang kota yang selalu berhadapan masyarakat di mana mesinmesin telah menggantikan Tuhannya; sebagian besar masyarakat desa yang bermigrasi di Afrika, telah menanggalkan keyakinan agamanya".

Berdasarkan hasil survey Buchanan dan Ellis dan diperkuat hasil penelitian McCord di atas, dapat dikemukakan bahwa modernisasi yang menyangkut skularisasi tidak mematikan agama tetapi lebih sering mengubahnya. Manusia modern lebih menggunakan nalarnya sebagai alat utama untuk memahami dan mengendalikan hidupnya.

\section{Perubahan Msyarakat: Khendak Sejarah}

Jika manusia tidak mampu membuat sejarah, maka ia akan menjadi alat pembuat sejarah maupun jadi obyek sejarah (C.
Weright Mills).Kemajuan dunia bagaikan kuda balap. Apa saja yang maju bersama dunia akan disisihklan oleh seleksi alamiah (Chen Tu Hsiu)

Secara teoritis, menyusun atau menulis tentang sejarah akan mudah jika ada data, fakta dan informasi dalam bentuk lisasn atau dokumen. Akan tetapi, dalam prakteknya, tidak sedikit orang yang merasa kesulitan dalam membuat sejarah. Salah satu jawabannya adalah, karena tidak ada satu strategi perubahan yang dapat diterapkan secara universal. Karena itu, saran bagi orang yang ingin membuat sejarah "jika tidak mampu membuat secara universal, maka setidaknya untuk sebagian besar situasi". Saran berikutnya yaitu, harus mengetahui perbedaan antara strategi dan taktik. Strategi, mengacu kepada rencana umum tidakan sementara taktik, mengacu kepada tindakan nyata dan khusus yang berasal dari strategi. Contoh, strategi mengajari orang tetang sesuatu yang akan mengubah lingkungan sosialnya, maka strategi pendidikan dapat dilakukan melalui berbagai taktik di antaranya adalah propaganda, pidato, ceramah daniklan.

Walaupun demikian, dalam konsep atau teori tentang strategi perubahan ditegaskan bahwa, perubahan sangat dipengaruhi oleh revolusi. Kecuali itu, perubahan juga dipengaruhi oleh beberapa factor seperti: factor ideology, ide-ide, konflik dan factor struktur social.

Untuk meneliti situasi/memilih strategi perubahan yang tepat, sejumlah pertanyataan harus dijawab terlebih dahulu, yaitu apa target upaya perubahan itu? Siapa yang akan mempengaruhi perubahan itu? Dan metode apa yang akan digunakan dalam melaksanakan perubahan itu?

\section{a. Target Perubahan}

Paling tidak ada tiga target perubahan yaitu, 1) individual, 2) kelompok dan 3) struktur sosial. Akan tetapi, di antara ketiga target itu harus diutamakan target tredekat. Dalam hal ini, target terdekat bagi pembuat sejarah adalah perubahan individu 
walaupun pada akhirnya, perubahan itu akan mempengaruhi ketiga-tiganya.

\section{Individual sebagai Target}

Perubahan, didasarkan pada premis bahwa individu yang sudah berubah akan mempengaruhi tatanan social (kelompok atau organisasi). Meskipun yang menjadi target perubahan individu, tetapi sasaran akhirnya adalah kelompok (keluarga, kelas anak sekolah) atau struktur sosial. Untuk melaksanakan target ini, sejumlah startegi digunakan antara lain: strategi psiko-analisis, psikologi social, modifikasi terpadu atau strategi pendidikan. Setiap strategi ini, masing-masing memiliki asumsi yang berbeda.

Kelompok sebagai Target Perubahan, diasumsikan bahwa perubahan suasana akan mempengaruhi perubahan individu. Sementara nilai, sikap dan perilaku individu akan diubah melalui perubahan struktur social, atau melalui perubahan kelompok yang menjadi tempat individu berfikir dan bertindak. Untuk melaksanakan target ini, ada dua cara atau metode yanag dapat digunakan yaitu: mengubah komposisi kelompok dan mengubah proses atau struktur kelompok. Namun demikian, perubahan dalam kelompok mungkin dipengaruhi oleh perbedaan komposisi keanggotaan. Mengubah komposisi berarti mengubah keanggotaannya. Cara lainnya yaitu, mengubah struktur atau prosesnya.

Kelompok sebagai Target Perubahan, diasumsikan bahwa menjadikan struktur social sebagai target perubahan berarti memperhatikan perubahan yang lebih luas. Perubahan mendasar dalam struktur social terjadi, karena komitmen politik terhadap modernisasi. Komitmen ini tercermin dalam tindakan untuk mempercepat langkah kemajuan masyarakat. Sebagai contoh, perubahan structural dari masyarakat agraris menjadi masyarakat industri.

\section{b. Metode Perubahan}

Ada beberapa metode yang dapat digunakan dalam mempengaruhi perubahan, kesemuanya dapat dipilih berdasarkan asumsi tertentu. Chin dan Benne (1969:3251) mengklasifikasi ke dalam tiga jenis strategi yaitu: 1) strategi rasional-empiris, 2) strategi normative-edukatif, dan 3) strategi paksanaan-kekuasaan.

\section{Strategi}

rasional-empiris didasarkan asumsi bahwa, manusia adalah makhluq rasional dan akan menuruti keputusan mereka sendiri jika keputusannya itu ditujukan kepada mereka, sementara strategi normative-educative berasumsi bahwa manusia adalah makhluq rasional tetapi mengakui segala tindakannya didasarkan pada norma-norma social, pengetahuan dan kepentingan sendiri. Strategi ketiga yakni strategi paksaankekuasaan, berasumsi bahwa manusia bertindak berdasarkan hubungan kekuasaan.

\section{Analisa}

\section{a. Modernisasi yang Membahayakan}

Mempelajari dan memahami uraian di atas, diperoleh hasil bahwa untuk melaksanakan modernisasi terutama dalam bidang social dan ekonomi, diperlukan strategi yang pas sehingga dapat memperkecil dampak negatif yang ditimbulkannya. Hal ini karena tidak semua modernisasi berdampak negatif, bahkan jika modernisasi itu sesuai dengan kemauan masyarakat dan tidak mengganggu tatatan social atau nilai agama maka modernisasi sangat dibutuhkan. Modernisasi akan berdampak negatif, salah satunya adalah modernisasi yang berkaitan dengan skularisasi. Sebab salah satu sasaran skularisasi adalah mengutamakan kemampuan akal pikiran daripada anjuran agama; membebaskan diri dari "tekanan" dan "perlindungan" agama. Kedua sasaran ini mengarah kepada "pemujaan" terhadap hukum realitas. Realitas bagi skularis adalah kehidupan di dunia, Kehidupan di dunia lebih mementingkan material. Karena itu, tahapan akhir dari sasaran skularisasi adalah materialisme.

\section{a. Skularisasi dan Dampak yang Ditimbulkannya}


Kata modern, makna aslinya mengisyaratkan kepada suatu nilai yang serba positif yaitu canggih, ke-maju-an atau ke-kini-an. Perkataan modern bermakna canggih dan maju itu layak dan baik (laik) jika dihubungkan dengan istilah Iptek, sebab setiap produk Iptek harus mengalami kemajuan (perubahan) yaitu peningkatan kemampuan dan kekuatan serta kesiapan masyarakatnya sebagai operator dan distributor teknologi (Nurcholis Madjid melalui Donal Smith, 1989:v). Dengan makna seperti ini, maka yang dimaksud dengan masyarakat modern adalah masyarakat yang maju dan trendi jika dibandingkan dengan masyarakat "pramodern".

Makna modern tersebut, akan terbalik jika kita amati sikap kehidupan masyarakat Eropa atau AS yang telah lama dikenal sebagai masyarakat modern dalam berbagai sektor kehidupan terutama sektor teknologinya yang sculer (sikap menentang realitas ilahi, Hamid Alghar dalam Altaf Gauhar, 1983:321). Karena itu, produk teknologi yang canggih sekalipun bagi masyarakat modern tidak lagi dijadikan standard kehidupan oleh masyarakat Eropa dan AS, karena hal itu telah menjadi pekerjaan rutin.

Berkaitan dengan produk teknologi yang canggih tadi, maka masyarakat Eropa dan AS sehingga mereka dapat dikategorikan sebagai masyarakat tradisional karena mereka yang telah berusaha melestarikan dan menjaga kesinambungan perilakunya itu secara turun temurun. Jika demikian, maka, yang dimaksud dengan masyarakat modern adalah masyarakat atau negara yang sedang berproses menuju kemajuan dan perubahan socio-culturnya sebagaimana yang tengah terjadi di beberapa negara berkembang. Ironisnya, sebagian masyarakat di beberapa negara berkembang memandang produk Iptek sebagai bentuk "perlawanan" karena berbenturan dengan sikap kehidupan mereka sehari-hari. Karena itu pula sehingga, tidak sedikit masyarakat di negara-negara berkembang yang beranggapan bahwa sikap modern sangat bertentangan dengan sikap hidupnya yang tradisionalist. Sikap perlawanan ini timbul, 1) karena masih ada kesan bahwa modernisasi tidak lain daripada pengembangan sikap, kebudayaan dan produk Iptek dari negara atau masyarakat modern yang ditanamkan kepada negara lemah, miskin dan bodoh. 2) pikiran, aliran, gerakan dan usaha masyarakat barat untuk mengubah faham-faham atau adat-istiadat agar disesuaikan dengan pendapat dan Iptek modern yang mereka ciptakan. Dengan kalimat lain, modernisasi bagi sebagian masyarakat di negara-negara berkembang identik dengan imperalisme.

Tidak terlalu salah pandangan sebagian masyarakat terhadap modernisasi, sebab proses modernisme yang terjadi di beberapa negara berkembang, salah satunya adalah karena penyebaran nilai-nilai modern yang dilakukan oleh negara-negara barat melalui kolonialisasi, imperalisasi dan distribusi produk Iptek seperti food, fashion dan fun yang ketiganya tersebar melalui media masa ataupun melalui cinema. Bentuk perubahan seperti ini oleh Dawam Rahardjo (1993) disebut proses perubahan exogenous. Terhadap bentuk perubahan ini Cak Nur (1992) berkomentar bahwa, kebudayaan modern yang merasuk ke beberapa negara berkembang, pada dasarnya adalah kebudayaan barat yang melanda ke seluruh dunia yang mampu menyapu bersih segala sesuatu yang menghadangnya. Hebatnya, lanjut Cak Nur, bangsa-bangsa tertentu yang bukan masyarakat barat, secara aktif berpartisipasi memperluas kebudayaan barat. Karena itu, sikap modern yang terjadi hingga kini, tidak hanya didominasi oleh negaranegara barat melainkan masyarakat negaranegara berkembang pun berusaha merubah sikap dari tradisionalisnya.

Terhadap pernyataan terakhir Cak Nur di atas, mas Dawam menyebutnya sebagai bentuk perubahan yang diakibatkan oleh gesekan nilai sosial ekonomi, budaya dan peradaban yang ditampilkan oleh sesama anggota masyarakatnya. Proses perubahan socio-cultur seperti ini menurut mas Dawam 
bukan karena proses perubahan exogenous melainkan karena proses perubahan endogenous.

Kronologis perkembangan pemikiran manusia tentang modernisme, menurut Hans Robert Jauss, sosiolog Jerman, (dalam Waheeduddin Khan, 1984) telah digunakan manusia sejak abad ke-5 M yaitu sebagai pembatas antara era Roma yang menyembah berhala (pagan era) dengan era Kristen yang menyembah Tuhan (theological stage). Pada saat itu, modernisme diartikan sebagai jalan pintas dari bentuk lama yang tradisional menuju ke bentuk baru yang modern. Istilah modernisme juga digunakan pada era renaisance pada abad ke 14-15 M yaitu digunakan untuk menunjukkan kebvangkitan kembali filsafat Yunani Kuno. Masyarakat Prancis menggunakan istilah modernisme pada abad $17 \mathrm{M}$ sebagai permulaan pembaharuan, karena menawarkan hal-hal baru seperti pengetahuan, moral, ilmu, kebudayaan, politik, seni dan lain sebagainya. Pada akhirnya, Jauss mengesimpulkan bahwa modernisme berarti suatu proses yang secara bertahap memuculkan karya klasik.

Modernisasi dalam bidang ekonomi, sosial dan budaya barat yang melanda ke beberapa negara berkembang selalu membawa dampak negatif dan mengandung ekses. Paling sedikit ada dua ekses yang ditimbulkan oleh sikap hidup modern terhadap kehidupan ummat dan ajaran agama. Ekses ini tidak hanya dirasakan secara langsung oleh penganut ajaran Islam Muhammad saw., melainkan kaum Kristiani, Budhis atau pun Hindu juga turut terganggu. Ekses pertama dan utama akibat dari pesatnya perkembangan Iptek yang bebas nilai (sculer), terutama bagi masyarakat yang belum siap mental, adalah kebebasan -bahkan tidak-- menganut agama. Sikap terhadap ajaran agama tidak lebih hanya sebagai instrumen belaka; ajaran agama dimanfaatkan sebagai alat justifikasi terhadap program-program resmi, atau sebagai suatu alat memotivasi dalam mencapai tujuan-tujuan tertentu yang terkadang berseberangan dengan nilai atau ajaran agama. Pada saat yang sama, praktek keagamaan tidak memperoleh dukungan maksimal bahkan seringkali terancam oleh lingkungan kerja yang mengikat. Ekses kedua adalah tumbuh sikap westwards atau peralihan kebudayaan dari kebudayaan masyarakat timur yang lugu, pemalu, toleran atau "penakut" ke suatu peradaban ala barat yang bebas, berani dan individualist.

Melihat keadaan seperti di atas, Dawam Rahardjo (1993) meramalkan ada tiga kemungkinan nasib suatu agama di masa-masa mendatang yaitu 1) agama semakin tidak relevan atau tidak fungsional dalam konteks modernisasi yang pada dasarnya adalah proses trans-industrialisasi dari negara-negara modern. 2) agama merupakan sumber perlawanan (resistance) peradaban modern, baik secara transfaran ataupun sembunyi-sembunyi. Bahkan kemungkinan lain yang akan terjadi adalah, 3) agama merupakan salah satu saluran dalam upaya untuk keluar dari tekanan sosioekonomi dan struktur politik; agama dijadikan sebagai tempat pelarian atas kekalahan kompetisi politik, ekonomi dan bisnis.

Terhadap ketiga kemungkinan di atas, orang yang melakukannya dapat dikategorikan sebagai perilaku dan perlakuan yang "menyimpang" terhadap fungsi dan peranan agama yang sesungguhnya. Sebab fungsi agama salah satunya adalah, "membersihkan diri dan mensucikan jiwa dan roh" (Harun Nasution, 1974:18); "hidup yang baik di dunia --baik dalam keluarga, negara atau dunia internasional-- agar di akhirat juga dapat hidup yang baik karena akhirat adalah kelangsungan hidup di dunia" (H. Rasyidi, 1977:14). Karena pada setiap agama, ummatnya dibekali kitab suci sebagai pedoman/panduannya hidup di dunia. Bagi ummat Islam, al-quran adalah panduan/pedoman utamanya. Melalui panduan itu, ummat Islam tidak akan tersesat selama berpegang kepada tali Allah dan bersilasturahmi dengan sesamanya (Qs. III:112) 
Tidak terlalu sulit untuk mencari amtsal atau beberapa contoh terhadap ketiga ramalan mas Dawam tersebut di atas, karena memang saking banyaknya jumlah perilaku social yang "menyimpang" yang dilakukan penganut suatu agama dalam memaknai fungsi dan peranan agama. Di bawah ini adalah dua buah contoh berkaitan dengan perilaku "menyimpang" yang dilakukan orang atau kelompok tertentu dalam memaknai fungsi agama.

Agama merupakan sumber perlawanan (resistance), salah satu contoh agama dijadikan sebagai perlaweanan terhadap peradaban modern adalah berhimpit atau berhadapannya antara bangunan masjid dengan mall. Bagaimana kaum muslimin merekonsiliasi mall dengan masjid? jawabannya sangat beragam dan sangat ditentukan oleh sikap fanatismenya kepada ajaran agama terutama dalam pengamalan keagamaan. Sementara masyarakat modern, yang diwakili masyarakat Eropa dan AS, menilai mall sebagai tandingan kontemporer bagi masjid. Mall bertindak sebagai focus social sehingga orang setia untuk pergi ke sana, karena mall adalah tempat untuk bersenang-senang para konsumeris, pesonanya senantiasa menggoda setiap saat karena di dalamnya terdapat barang (produk Iptek) yang selalu memikat. Dari aspek seni, mall adalah keajaiban kukltur konsumeris. Singkatnya, mall adalah simbol kesenangan, pasar dengan hiburan, ada ironi antara yang serius dengan yang santai; orang mengunjunginya untuk rileks (Akbar S. Achmad, 1993).

Sementara itu masjid adalah bangunan suci, yang di dalamnya terdiri dari orang-orang (yang berusaha) suci. Orang yang berada di dalam masjid, tidak memiliki pilihan lain kecuali berdzikir dan bermunajat hanya kepada Allah swt. saat itu, melalui i'tikaf terutama saat pelaksanaan shalat fardlu atau shalat jum'at, orang tidak diperkenankan "bersenang-senang". Masjid menjauhkan orang-orang beriman dari kerasnya kehidupan sehari-hari; tempat di mana memperoleh ketenangan dan kedamaian menjadi karakternya. Orang beriman terdorong untuk berpikir tentang Tuhan yang abadi dan fananya hidup di muka bumi ini. Karena itu masjid adalah symbol bagi orang yang berusaha menjauhkan diri dari keramaian pasar, kesenangan dan duniawi.

Masjid versus mall, yang satu merupakan paradigma kesalehan, memberikan gaya hidup altrernatif, yang satunya lagi adalah surga warna dan kesenangan. Generasi muda muslim yang akan datang harus melakukan pernyesuaian dan mengekspresikan pilihannya.

Agama sebagai Saluran Keluar dari Tekanan Social, Ekonomi dan Politik, salah satu contoh agama dijadikan sebagai saluran untuk keluar dari tekanan socialekonomi, politik, dan bisnis adalah moment hari Jum'at. Pada hari Jum'at, ada momen berkumpulnya antara ulama dan ummatnya melalui shalat Jum'at. Fungsi utama shalat Jum'at adalah interaksi positif antara ulama (khathib) dengan ummatnya. Melalui materi khatbahnya, khtathib berwashiat dan memberikan nashihat kesabaran dan ketaqwaan. Akan tetapi, bagi orang atau kelompok tertentu yang memahami hari Jum'at sebagai sayyid al-ayyam, ada yang memanfaatkan momen jum'atan ini untuk mensosialisasi program partai politik, bahkan kampanye politik kepada masyarakat. Sebagian yang lain, ada juga yang memanfaatkan mimbar atau khutbah jum'at untuk memfitnah, menjelek-jelekkan orang atau kelompok lain yang tidak sefaham dengannya.

Kedua contoh di atas, tampaknya layak dikedepankan untuk dijadikan sebagai pengetahuan bahwa ternyata perilaku social yang "menyimpang"terjadi di mana-mana dan orang cenderung untuk melakukannya setiap saat. Hebatnya, kenyataan ini tengah melanda di berbagai strata kehidupan social; tidak hanya dilakukan oleh para elit politik, tetapi para tokoh agama juga terjebak oleh perilaku sosial yang "menyimpang".

\section{c. Sikap Muslim Kontemporer}


Dapat dikemukakan bahwa, salah satu mission sacre masyarakat barat melalui modernisasinya yaitu agar masyarakat muslim menjadi terkotak-kotak: 1) sebagian ada yang tetap tradisionalis yaitu mereka yang selalu konsisten terhadap nilai-nilai ajaran Islam dan hanya berpegang kepada alquran dan al-sunnah; 2) sebagian yang lain menjadi modernis yang akan merasakan "manisnya" modernisasi, mereka adalah muslim tradisional yang mampu beradaptasi dengan kehidupan modern, baik dalam cara berpikir maupun dalam berperilaku; 3) sebagian lainnya yaitu memilih di antara keduanya yaitu sekelompok muslim yang konsisten melaksanakan tradisi suci keislmaman tetapi hidup di tengah-tengah masyarakat skuler, atau muslim modern yang hidup di tengah-tengah masyarakat yang kebanyakan tekun dan taat melaksanakan ajaran Islam.

Kaum muslimin yang terakhir, dapat kita sebut sebagai muslim kontemporer yaitu muslim yang selalu berhadapan dengan perlawanan sejarah. Muslim kontemporer sebagai muslim tradisional, mereka akan berhadapan dengan kekuatan skularisme yang lebih mengutamakan kebahagiaan sesaat (hedonisme) dalam bentuk konsumeristis, materialistis atau bahkan liberialistis. Sebaliknya muslim kontemporer sebagai muslim modern, mereka akan berhadapan dengan kekuatan tradisionalisme yaitu sistem peribadatan yang mengikat, loyalitas group dan saling mempercayai.

Jika posisi kita sebagai muslim kontemporer, maka apa sikap kita ketika berhadapan dengan peradaban modernisme yang hedonis? Pertama yang harus dilakukan adalah mengembalikan segala persoalan hanya kepada Allah swt dan rasulNya. Sikap seperti ini layaknya penganut faham fatalisme, yang lebih mempercayakan segala persoalan hidupnya hanya kepada Allah swt. padahal Allah telah berfirman dalam Qs. XIII:12 yang artinya, sesungguhnya Allah tidak mengubah keadaan suatu bangsa sampai mereka mengubahkan sendiri . Ayat ini ditafsirkan oleh Jamaluddin al-Afgani yaitu, "manusia sendirilah yang paling bertanggung jawab terhadap perubahan social (social change)"

Kedua, memilih dan memilah persoalan atau perilaku sosial yang tidak sesuai dengan aspek-aspek ajaran Islam. Menetapkan sikap seperti ini telah diajarkan oleh ajaran Islam bahwa, persoalan dunia merupakan persoalan manusia, karena itu manusialah yang lebih mengetahuinya. Sehingga pada hadits lain Rasulullah Muhammad saw. menyarankan kepada ummatnya agar, memiliki ilmu pengetahuan untuk mengarungi bahtera di dunia maupun di akhirat

Ketiga, jika kita mampu maka pengaruhilah ikhwan kita yang telah terpengaruh menjadi skularis yang lebih mengutamakan sikap hidup hedonisme, konsumerisme atau bahkan materialisme. Sikap muslim kontemporer yang sangat bermanfaat ketika berhadapan dengan sikap skularis yaitu, bergaulah dengannya lalu rubahlah substansi skularismenya dan alihkan menjadi sikap tradisionalis suci yang selalu berdasar kepada al-quran dan alsunnah. Sebagaimana disarankan Rasulullah Muhammad saw yang sering kita kemukakan dan kita dengar dari orang lain yaitu, barang siapa yang menghadapi suatu kemungkaran maka rubahlah dengan tanganmu, jika tidak mampu maka rubahlah dengan lisanmu, jika tidak mampu juga maka lebih baik diam walaupun dalam keadaan demikian keimanan kita semakin lemah.

\section{Implikasi dan Impementasinya terhadap Pendidikan Masyarakat}

a. Implikasinya

Ada implikasi positif dari strategi perubahan berkaitan dengan modernisasi industrialisasi, khususnya dalam bidang pendidikan dan pelatihan (Diklat). Salah satu implikasi positifnya yaitu bahwa, masyarakat mulai menaruh perhatian terhadap program PLS dengan tidak memandang sebagai program yang hanya berpihak kepada masyarakat ekonomi lemah. Sebagai contoh, Program-program Diklat yang dilaksanakan 
oleh PP Darut Tauhid bandung (antara lain pelatihan Manajemen Qalbu). Walaupun penyelenggaranya adalah Pondok Pesantren (symbol lillahi ta'ala) yang lebih concern terhadap keakhiratan nyatanya mampu merebut "pasar" sehingga peminat MQ tidak hanya berasal dari kalangan ekonomi lemah melainkan para manajer perusahaan terkenal juga turut mengadop system Diklat yang dikembangkan PP Darut Tauhid. Mengapa demikian? Karena program PLS (Diklat MQ) dikemas sedemikian rupa sehingga masyarakat menghargainya sebagai kegiatan yang bernuansa ekonomi/bisnis (salah satu ciri khas PLS) tidak lagi sebagai proyek atau ladang ibadah (salah satu ciri khas program Pondok Pesantren)

b. Implementasinya

Konsep dan pembahasan tentang strategi perubahan, erat berkaitan dengan konsep innovasi dan upaya pengembangan PLS. Ada banyak prinsip, metode, pendekartan atau strategi perubahan yang dapat diadopsi dan diadaptasikan menjadi suatu model yang dapat diterapkan pada usah-usaha pengembangan PLS. Salah satunya adalah Pendidikan Anak Dini Usia (PADU) yang belakangan ini mulai memperoleh perhatian penuh dari pemerintah dan masyarakat.

Munculnya banyak permintaan masyarakat terhadap pemerintah untuk mendirikan lembaga pendidikan pra-sekolah seperti TK, play group dan sejenisnya seharusnya menjadi fenomena penting sehingga menimbulkan inspirasi dan motivasi untuk lebih mengupayakan ekstensifikasi dan intensifikasi dalam pelasksanaan program PLS. Sehingga hal itu bisa meningkatkan komitmen keikutsertaan PLS dalam berbagai upaya untuk menanggulangi permasalahan yang terjadi di masyarakat.

Pendirian lembaga seperti TK, Play Group, ataupun lembaga pra-sekolah lainnya pada mulanya hanya karena perhatian beberapa orang tua yang concern terhadap pendidikan anak-anak di masa depan.
Sehingga, dalam pelaksanaannya terkadang ditangani oleh masyarakat yang tidakmemiliki pengetahuan apalagi pengalaman tentang mendidik anak usia batita (murid play group) atau usia balita (murid TK). Dampaknya, fihak penyelenggara kurang memperhatikan aspek kemampuan dan kemauan warga belajar (murid TK) melainkan lebih mempertimbangkan kehendak/kemauan dan kemampuan orang tua murid. Dampak berikutnya adalah, tidak sedikit dari murid SD klas I s.d III belum bisa beradaptasi bahkan tidakbisa mengikuti pola belajar di SD lantaran mentalnya masih seperti murid TK.

Harus diakui secara jujur bahwa secara konseptual, lembaga pra-sekolah merupakan program PLS dalam upaya penanganan terhadap permasalahan pendidikan masyarakat. Karena itu, jika PLS concern dengan upaya peningkatan kemampuan kognitif, psikomotor dan penanaman perilaku dan sikap dalam menunjang aktualisasi diri dan kemandirian peserta didik. Maka perlu dipikirkan strategi yang jitu dalam penanganan pendirtian TK, Play Group atau pra-sekolah sejenisnya.

\section{Daftar Bacaan}

\section{Buku Rujukan}

Lauer, Robert H. 1993. Perpektif tentang Perubahan Sosial. Jakarta: Penerbit Rineka Cipta.

\section{Buku Pendukung}

Achmad, S., Akbar, 1993. Posmodernisme Bahaya dan Harapan bagi Islam. Bandung: Mizan.

A. Munir dan Sudarsono. 1994. Aliran Modern dalam Islam. Jakarta: Rineka.

Dawam Rahardjo. 1993. Intelegensia dan Intelektualitas. Bandung: Mizan.

Departemen Agama RI. 1987. Al-Quran dan Terjemahannya. Jakarta: 
Dean C. Tipps. 1973. Modernization Theory and the Comparative Dtudy of Societies: "A Critical Perpective", Comparative Studies in Society and History 15,

Gauhar, Altaf, 1983. Tantangan Islam, Pustaka Salman. Bandung: ITB.

Harun Nasution. 1974. Islam Ditinjau dari Berbagai Aspek. Jakarta: UI Press.

Khan, Waheeduddin. 1984. Islam Menjawab Tantangan Jaman. Bandung: Pustaka Salman ITB.

Norman S. Buchanan and Howard S. Ellis. 1955. Approaches to Economic Development. NY: Twentieth Century Fund.

Nurcholis Madjid. 1992. Islam Doktrin dan Peradaban. Jakarta: Paramadina Press.

Rasyidi. 1977. Koreksi terhadap Islam Ditinjuau dari Berbagai Aspek. Jakarta: Bulan Bintang.

Robert Chin and K.D Benne. 1969. General Strategies for Effecting Changes in Human Systems dalam The Planning of Change. NY: Ed. Warren G. Rinehart and Wiston.

Smith, Donal. 1989. Sosiologi Agama. Jakarta: Rajawali Press. 